3 Hashimoto H, Kishi S. Shortening of the rod outer segment in Oguchi disease. Graefes Arch Clin Exp Ophthalmol 2009; 24: 1561-1563.

4 Takada M, Otani A, Ogino K, Yoshimura N. Spectral-domain optical coherence tomography findings in the Mizuo-Nakamura phenomenon of Oguchi disease. Retina 2011; 31: 626-628.

5 Robson AG, Mengher LS, Tan MH, Moore AT. An unusual fundus phenotype of inner retinal sheen in X-linked retinoschisis. Eye (Lond) 2009; 23: 1876-1878.

6 Nishiguchi KM, Sandberg MA, Kooijman AC, Martemyanov KA, Pott JW, Hagstrom SA et al. Defects in RGS9 or its anchor protein R9AP in patients with slow photoreceptor deactivation. Nature 2004; 427: 75-78.

7 McBain VA, Egan CA, Pieris SJ, Supramaniam G, Webster $\mathrm{AR}$, Bird AC et al. Functional observations in vitamin A deficiency: diagnosis and time course of recovery. Eye (Lond) 2007; 21: 367-376

PI Sergouniotis ${ }^{1,2}$, AE Davidson ${ }^{1}, \mathrm{~K}$ Sehmi², AR Webster ${ }^{1,2}$, AG Robson ${ }^{1,2}$ and AT Moore ${ }^{1,2}$

${ }^{1}$ UCL Institute of Ophthalmology, London, UK

${ }^{2}$ Moorfields Eye Hospital, London, UK

E-mail: tony.moore@ucl.ac.uk

Eye (2011) 25, 1098-1011; doi:10.1038/eye.2011.88;

published online 15 April 2011

Sir,

\section{Development of optic disc drusen in familial pseudopapilloedema: a paediatric case series}

Optic disc swelling in a child, with no other features suggestive of raised intracranial pressure is a challenging clinical scenario. These children frequently undergo invasive investigations, such as neuroimaging and lumbar puncture, even though the clinical suspicion of serious pathology is low.

In this study, we report a new clinical presentation of benign optic disc swelling in five siblings of two families, where optic disc drusen were not present at first presentation, but developed many months later as shown on serial B-scan ultrasonography. We have termed this unusual presentation 'familial pseudopapilloedema'.

Five children (two siblings from one family and three siblings from another family) underwent examination and B-scan ultrasonography at first presentation and at all subsequent examinations. Age range at first presentation was 18 months to 12 years with a mean of 6.5 years. The male to female ratio was $4: 1$. All five children had clinically apparent optic disc swelling without other ophthalmoscopic features of papilloedema (retinal nerve fibre layer swelling, surrounding disc haemorrhages, cotton wool spots, hyperemia, venous congestion, Patton's lines, or exudates ${ }^{1}$ ). None had any symptoms suggestive of raised intracranial pressure, other neurological disease, or systemic upset (Table 1).

Serial B-scan ultrasonography showed no drusen at the first visit. However, all children developed small linear drusen at the optic disc over time (Figure 1). The mean time for development of drusen detectable on B-scan was 2.7 years. At no point was there optic nerve sheath dilation on B-scan. In two children, CT scans were conducted and reported as normal. A CT scan was avoided in three children because of the absence of optic nerve sheath swelling on sonography, the absence of symptoms of raised intracranial pressure and normal visual function. ${ }^{2,3}$

Table 1 Summary table showing each of the five children's age, reason for presentation, vision, refraction, and investigations

\begin{tabular}{|c|c|c|c|c|c|}
\hline & $A 1$ & $A 2$ & $A 3$ & B1 & $B 2$ \\
\hline Age at presentation & 18 months & 4 years & 6 years & 12 years & 7 years \\
\hline $\begin{array}{l}\text { Time taken for optic } \\
\text { disc drusen to become } \\
\text { visible on B-scan }\end{array}$ & 12 months & 18 months & 4 years & 3 years & 4 years \\
\hline $\begin{array}{l}\text { Reason for referral } \\
\text { to our unit }\end{array}$ & $\begin{array}{l}\text { Family history } \\
\text { of optic disc } \\
\text { drusen }\end{array}$ & $\begin{array}{l}\text { Optometrist referred } \\
\text { for possible drop } \\
\text { in visual acuity }\end{array}$ & $\begin{array}{l}\text { Optometrist noted } \\
\text { possible swollen } \\
\text { optic discs on } \\
\text { routine visit }\end{array}$ & $\begin{array}{l}\text { Optometrist } \\
\text { referred } \\
\text { for 'problems } \\
\text { focusing' }\end{array}$ & $\begin{array}{l}\text { Optometrist referred } \\
\text { for possible swollen } \\
\text { optic discs on } \\
\text { routine visit }\end{array}$ \\
\hline $\begin{array}{l}\text { Refraction at last } \\
\text { visit: right eye }\end{array}$ & $+2.50 \mathrm{DS}$ & $+2.50 \mathrm{DS}$ & $+3.50 /+0.50 \times 90$ & -0.25 DS & $+0.50 /-0.25 \times 180$ \\
\hline $\begin{array}{l}\text { Refraction at last } \\
\text { visit: left eye }\end{array}$ & +2.25 DS & $+2.50 \mathrm{DS}$ & $+3.50 /+0.25 \times 90$ & $-0.50 \mathrm{DS}$ & $+0.50 /-0.25 \times 175$ \\
\hline $\begin{array}{l}\text { Vision at first } \\
\text { presentation }\end{array}$ & $\begin{array}{l}\text { 6/7.5 BEO } \\
\text { (Cardiff Cards) }\end{array}$ & $\begin{array}{l}\text { R 6/7.5, L 6/7.5 } \\
\text { (Snellen) }\end{array}$ & $\begin{array}{l}\text { R 6/6, L 6/6 } \\
\text { (Snellen) }\end{array}$ & $\begin{array}{l}\text { R 6/6, L 6/5 } \\
\text { (Snellen) }\end{array}$ & R 6/6, L 6/5 (Snellen) \\
\hline Visual fields & No & No & Yes-Normal & Yes-Normal & $\begin{array}{l}\text { Yes-Enlarged blind } \\
\text { spot, otherwise normal }\end{array}$ \\
\hline Lumbar puncture & No & No & $\begin{array}{l}\text { Yes-Opening pressure } \\
35 \mathrm{~cm} \mathrm{H}_{2} \mathrm{O}\end{array}$ & No & No \\
\hline CT scan & No & No & Yes-Normal & Yes-Normal & No \\
\hline
\end{tabular}

A and B represent different families. 1, 2 and 3 represent different children within the families.

BEO denotes both eyes open.

Normal VF $=$ No constriction to I4e, I2e, or V4e spot on the Goldmann Kinetic Perimeter. 


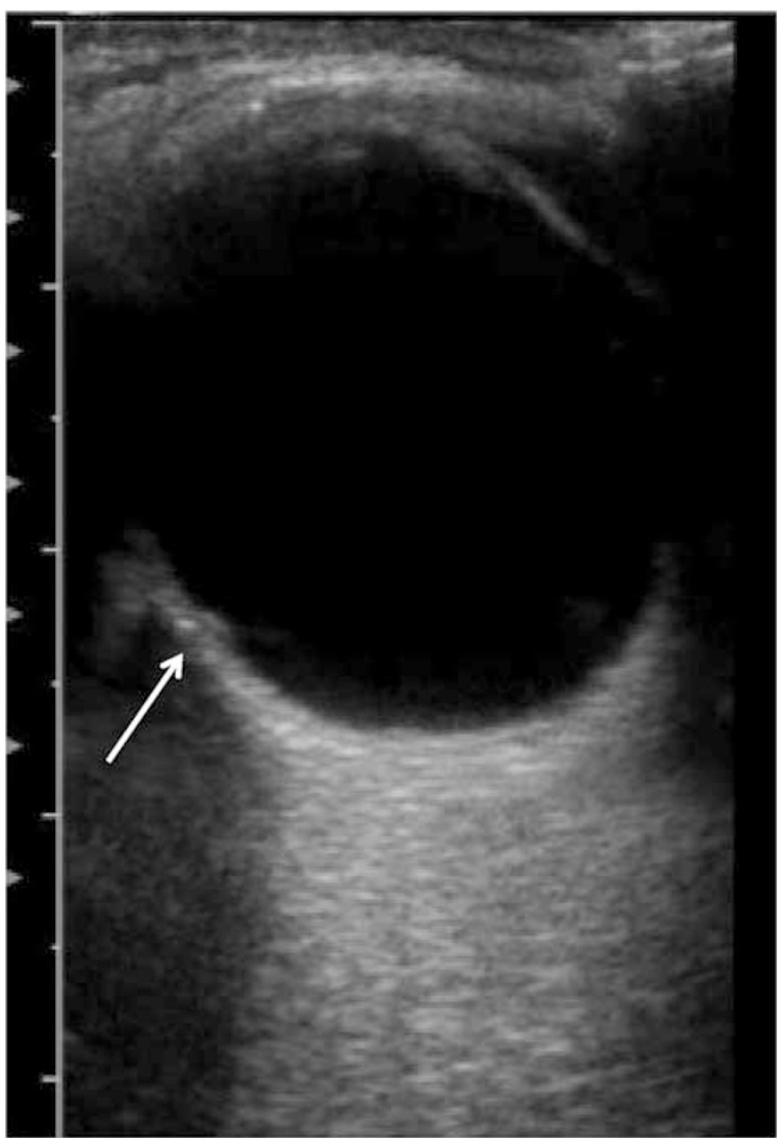

Figure 1 B-scan of small linear disc drusen (arrow) in one of the subjects.

\section{Discussion}

This is the first description of development of optic drusen in related children with pseudopapilloedema. ${ }^{4,5}$ We found that reassuring symptomatology, the absence of optic nerve-sheath swelling on B-scans and a positive family history of pseudopapilloedema to be very helpful in excluding serious intracranial pathology, as well as reducing the need for lumbar punctures and CT scans.

\section{Conflict of interest}

The authors declare no conflict of interest.

\section{References}

1 Rosenberg MA, Savino PJ, Glaser JS. A clinical analysis of pseudopapilloedema. Population laterality, acuity, refractive error, ophthalmoscopic characteristics and coincident disease. Arch Ophthalmol 1979; 97(1): 65-70.

2 Brenner DJ, Hall EJ. Computerised tomography - an increasing source of radiation exposure. N Eng J Med 2007; 357: 2277-2284.

3 Kurz-Levin MM, Landau K. A comparison of imaging techniques for diagnosing drusen of the optic nerve head. Arch Ophthalmol 1999; 117: 1045-1049.

4 Lorentzen SE. Drusen of the optic disc, an irregularly dominant hereditary affection. Acta Ophthalmol 1961; 39: 626-643.
5 Antcliff RJ, Spalton DJ. Are optic disc drusen inherited? Ophthalmology 1999; 106: 1278-1281.

\author{
H Petrushkin', N Ali², M Restori and GGW Adams² \\ ${ }^{1}$ Royal Free Hospital, Ophthalmology Department, \\ London, UK \\ ${ }^{2}$ Moorfields Eye Hospital, London, UK \\ E-mail: harrypetrushkin@gmail.com
}

Eye (2011) 25, 1101-1102; doi:10.1038/eye.2011.95; published online 6 May 2011

\section{Sir, \\ Eccrine syringofibroadenoma of the eyelid in association with eye prosthesis}

Eccrine syringofibroadenoma (ESFA) is a rare benign adnexal eccrine neoplasm. We report an ocular presentation with a unique location in the eyelid, associated with enucleation and long-standing prosthesis.

\section{Case report}

A 65-year-old man was referred to our eye clinic with a superomedial eyelid lesion just posterior to his lash line (Figure 1). The mass was present for 3 years and was slowly enlarging. He had undergone a left enucleation at the age of 1 year for a congenital abnormality of unknown aetiology and had a well-fitted prosthesis in situ.

The lesion was a $9 \mathrm{~mm} \times 5 \mathrm{~mm} \times 3 \mathrm{~mm}$, solitary, elevated, non-tender polypoid mass on the under surface of the upper left eyelid posterior to the gray line. (Figure 1). His eye socket was unremarkable and there were no other cutaneous lesions. Microscopy of an excisional biopsy revealed downward proliferation of surface squamous epithelium, with thin strands of interconnecting epithelial cords and adjacent proliferation of conjunctival epithelium including goblet cells (Figures 2a and b). Epithelium surrounding a fibrovascular stroma was identified, and immunostaining with carcinoembryonic antigen showed

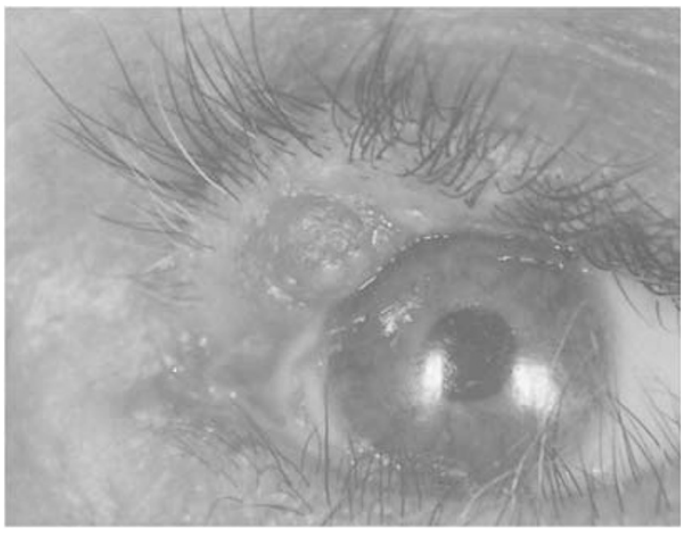

Figure 1 Solitary, elevated, non-tender polypoid ESFA on the under surface of the upper left eyelid posterior to the gray line. 